\title{
Perspectives of Use of Alternative Energy Sources in Air Transport
}

\section{Luboš Socha $^{1 *}$, Vladimír Socha ${ }^{2}$, Peter Čekan ${ }^{1}$, Daniela Čekanová ${ }^{1}$, Lenka Hanáková², Tomáš Puškáš ${ }^{1}$}

\footnotetext{
${ }^{1}$ Department of Air Transport Management, Faculty of Aeronautics, Technical University of Košice, Košice, Slovak Republic

${ }^{2}$ Department of Air Transport, Faculty of Transportation Sciences, Czech Technical University in Prague, Prague,

Czech Republic
}

*Corresponding author:Technical University of Košice, Faculty of Aeronautics, Department of Air Transport Management, Rampová 7, 04112 Košice, Slovak Republic, Email: lubos.socha@tuke.sk

\begin{abstract}
The problem of environmental load is also reflected in air transport. Usage of fossil fuels, which are dominant nowadays, has a negative impact on the environment and also its resources are limited. Therefore, the article focuses on the prospective of use of other energy sources in aviation, such as alternative fuels (synthetic fuels, biofuels, alcohol, methane, hydrogen), solar energy and the use of fuel cells. Also, the paper briefly summarizes the approach of aircraft manufacturers to the use alternative sources.
\end{abstract}

Keywords

Airline - Alternative energy sources - Environment - Fuel

\section{Introduction}

Petroleum products are the basic material for the production of aviation fuels. In addition to offering the best combination of energy content, power, availability, ease of handling and prices and risks in energy security, climate changes, long-term availability and price increases, which naturally leads to the search for alternative solutions.

Although the current aviation industry is highly dependent on the power unit conventional fossil fuels, the use of these fuels is not sustainable in the long term especially in terms of the limited resources of raw materials and high impact on the environment $[1,2]$.

At the same time fuel prices, which are directly related to the world's oil prices constitute a significant component of aircraft operating costs. In the near future is expected to be non-decreasing price of oil and the oil itself is one of the non-renewable resources which reserves are declining.

Of the world's fossil fuel accounts for $10 \%$ of aviation emissions and discharges of greenhouse gas carbon dioxide produced by the burning comes with the $2 \%$ [3]. Replacing fossil fuels for aviation by renewable and alternative energy sources is difficult, but necessary. Of course, that new solutions must be designed with an emphasis on safety and reliability of the engine and aircraft operation and the overall safety must not be endangered in any way. 


\section{Alternative fuels for aviation}

Considering today's alternative fuels for aviation engines, we are indeed limited to use alternative sources of fuel derived from kerosene. New concepts and approaches to the application of alternative energy sources are associated with the development of new power units applying new technologies that go beyond today's specifications and requirements. This is connected with questions such as $[4,5]$ :

- Potential certification,

- Compatibility with conventional jet fuel,

- Fuel handling infrastructure.

Alternative fuels for aviation have constituted a new concept since the energy crisis in the second half of last century. All leading manufacturer in the aviation market deal with the investigation of aircraft engines using alternative fuels reducing fuel costs, improving safety and positive impact on the environment.

Alternative fuel sources for aviation must meet the essential requirements [6]:

- Sufficient supplies,

- Adequate supply,

- Not controlled by a factor of fossil fuel,

- Availability of fuel.

\subsection{Synthetic fuels}

Currently used synthetic jet fuels are produced by the Fischer Tropsch processes. This process enables the production of liquid hydrocarbon fuels from natural gas, coal, bituminous shale and biomass, even free of sulphur and aromatic compounds, which generally does not result in the release of any carbon dioxide from incineration.

Thus produced synthetic fuels are currently comparable in the performance and chemical composition with the use of conventional aviation fuel.

They are characterized by excellent properties in a wide temperature range. In external low ambient temperature they have good viscosity, higher hydrogen-carbon ratio due to a zero content of aromatics and sulphur, which result in reduced percentage of exhaust gases on combustion. All these features along with good performance enable ease of complementing existing fuel supplies with synthetic fuels.

Fuel produced by mixing synthetic Fischer-Tropsch fuels with conventional fuels is the easiest technical solution to the issue of alternative fuels for jet aircraft [7].

\subsection{Bio fuels}

Still more discussed alternative source of fuel is biomass. Biomass in the form of plants is chemically conserved solar energy and at the same time it is one of the most versatile and most widely used energy source on the Earth. The liquid and gaseous forms are ethanol, methanol, wood gas, bio-gas, which can be used as fuel.
The advantage is that it offers not only a great variety of raw materials, but also universal applications in energetic.

The main disadvantage of biomass as an alternative source of fuel is a lot of oxygen in the molecular structure, thus achieving lower energy content than hydrocarbons, which results in a reduction of flight range when using these fuels [8].

\section{Biodiesel fuels}

The term biodiesel entails a large amount of material produced from animal fats or vegetable oils. Resources for making this possible alternative jet fuel additionally to kerosene are soybean oil, rapeseed oil, and coconut oil and palm trees. As the fuel the material used is resulting from the pre-esterification, the process in which the fats and oils are combined with methanol, thereby, to reach pre-transformation of triglycerides to the methyl ester of fatty acids with properties similar to conventional diesel fuel [9].

\section{The advantages of using bio fuels are [9]:}

- Lower carbon footprint when compared with conventional jet fuel,

- The same or higher energy content when compared with conventional jet fuel,

- Do not endanger biodiversity.

\subsection{Other alternative fuels}

Currently, there are in addition to bio fuels and synthetic fuels other known alternative fuel options mentioned as possible fuel.

\section{Alcohol}

Such as butanol, methanol, and ethanol may also be used as fuel, but are remarkably poor in combustion characteristics and, because of the presence of oxygen in their molecular structure, have a low energy content. For commercial aviation, however, they are at this time practically unusable [10].

\section{Methane}

The use of methane as a component of natural gas is forced by achieving its liquid state, which means its storage at cryogenic temperatures and the concept of a new type of power units and create new conditions for storage, distribution and transportation [10].

\section{Hydrogen}

The most eco-inflected alternative to oil. The production requires large amounts of electricity derived from other types of energy and the need for substantial sources of clean water. Despite its clean burning and emission of no carbon dioxide, this raises a number of problems with the production, handling and storage. Its prospective use is in their application in fuel cells used to power an aircraft [10]. 


\section{Electric drive systems}

The development of electric drive systems offers the long-term perspective approach of the positive impact of aviation on the environment and global climate.

Electrical systems through which the aircraft is in motion are constructed from fuel cells and solar panels or power batteries.

\subsection{Solar cell}

The research of solar aircraft has been under way since 1980 at NASA. The concept of a solar plane is actually very simple. An aircraft provided with solar cells that often cover the wings, tail, and sometimes a part of fuselage, receives solar energy emitted by the sun, to allow power for the driving system and control electronics while charging the battery by excessive, the residual energy. Electrical energy available from the battery is later used to power an aircraft mainly during the night, at dusk, in the east, and sunset. The first ever flight with the help of solar energy was controlled on 4 November 1974 by the remote-controlled aircraft with the name SUNRISE II. The first flight flown during the night, we can consider the record flight flown in April 7, 2010, which pushed the boundaries of art and technology of solar aircraft.

The total length of time spent in the sky of the aircraft Solar Impulse with its wingspan comparable to Airbus A340 was over 26 hours due to the small power consumption drawing from batteries.

Aircraft with a wing span of 63.4 meters reached their maximum flight altitude 8564 meters above the sea level at an average speed of $70 \mathrm{~km} / \mathrm{h}$. The main limiting factor of aircraft powered by solar panels is the weight that, due to the location of panels on the surface of the fuselage and also the batteries necessary for storing the residual energy, increase the aircraft weight of, thereby, inevitably increasing the consumption of the energy for the operation [11].

\subsection{Space solar power}

The use of solar radiation via solar cells to power an aircraft is not the only possible solution that offers us the rays of the sun. Capitalization of solar energy is possible on the basis of building the space solar power. "Space Solar Power" the space solar energy also known under the term "Solar Based Solar Power (SBSP)".

Outer space solar power is another possible alternative source of energy. The outer space solar power collects energy directly from sunlight via large solar panels placed on satellites in the space orbit and transmits it on the ground or into the aircraft. Positive aspects of this approach are [12]:

- No greenhouse gas emissions, in contrast to the use of oil, gas or ethanol for the aircraft driving,

- Space solar power produces no harmful waste such as nuclear power plants, which must be safely stored and kept,
- Compared with terrestrial solar and wind power is solar space available 24 hours a day, 7 days a week in vast quantities and flows despite clouds, daylight or wind,

- Space solar power is not a tempting target for terrorists as are other types of power plants, especially nuclear,

- Can be exported to any one of cities in the world.

On the other hand, the costs are:

- High development costs,

- High demands on technology and building up the space infrastructure: the implementation of the concept requires a gentler rockets, causing an increase in requirements and costs,

- More traffic and construction in orbit: enormous energy needs large solar satellites. The concept of space solar energy requires the necessary of structural and technological changes of aircraft and airport systems. The aircraft must be equipped with a device for receiving and converting the resulting energy into electrical energy. To obtain the energy it is needed to build and install satellite infrastructure in the space.

\subsection{Fuel cells}

These are future developments in the field of propulsion. The principle of the fuel cell has been known for a long time and more significantly contributed to the application of the current space program in the sixties of the twentieth century. A fuel cell is an electromechanical device, the reactor that converts hydrogen into electricity by combining hydrogen fuel with oxygen from the air in the so-called "Dry burning" in the increased production of pure water and heat.

The program has demonstrated its safety as a source of electrical energy compared with energy generated by a nuclear reactor as well as the lower price compared to solar cells. The actual cells present operation of air transport without greenhouse gas emissions, carbon dioxide and quieter engines as in driving by hydrocarbon fuels.

Achieving high efficiency and very low environmental load belongs to its most important features. The batteries are different because of their continuous production of electricity in the presence of oxygen for starting and constant source of fuel [5].

\section{Attitude of aircraft manufacturers to alternative sources}

Two largest producers of aircraft are engaged in the field of alternative fuels for aviation independently. This issue is familiar to both Airbus and even its biggest competitor Boeing.

\subsection{Airbus company}

The company pioneered the implementation of a sustainable sources of bio fuels in aviation, which is achieved through the reduction of carbon dioxide escaping into the atmosphere. 
The first step to implementing alternative fuels for aviation in 2008 was a three-hour flight of the Airbus A380 powered by synthetic fuels processed by Fischer Tropsch process from Filton airport in the UK. Second commercial flight using the same fuel followed in 2010 by United Airlines in operating an aircraft Airbus A319. Other flights using alternative fuels have been carried out by companies Qatar Airways, Tam Brazil, Luftahansa operating Airbus. Experimental and research flights have demonstrated the possibility of replacing fossil fuels, synthetic fuels without modifying the types of aircraft. Airbus in cooperation with the European Commission, the leading bio fuel producers and the airlines gave an impetus to the accelerated introduction of bio fuels into the aviation [13]. Joint efforts of the entire industry called "Bio fuel Flight path" announced in June 2011, sets clear milestones to focus on the production of two million tons of bio fuels produced in a sustainable way for the Air Force by 2020. The plan promotes and emphasizes the need for the construction of industrial production of bio fuels plants [14].

Currently, the aircraft manufacturer Airbus for achieving the objectives in the field of alternative fuels also working with other companies such as the National Romanian airline Tara for the use of bio-kerosene fuels produced for jet engines, Iberia Airlines to support the initiative focused on the development of the Spanish 'value chain' for sustainable alternative bio fuels with Australia when converted eucalyptus trees on alternative fuels through a process called "paralysis", and like [13].

The Airbus Company estimates of $30 \%$ of commercial flights of sustainable bio fuels as early as in 2030 [13].

The application of bio fuels as an alternative source of aircraft driving also the application of fuel cells as a source of electrical power mean for Airbus promising technologies and present great potential to make significant drop in external noise, fuel consumption and emissions of greenhouse gas carbon dioxide. The Airbus Company with its partners, producer Michelin and German National Research Centre for Aeronautics and Space Administration conducted research, which focused on the integration of fuel cells on board of aircraft. In the testing flights of civil aircraft Airbus A320, the fuel cells were used as a power source to supply back-up systems of the aircraft. During the flight the fuel cell system produced up to $20 \mathrm{~kW}$ of electricity. The system was powered by an electric motor pump serving for hydraulic backup circuit to control the aircraft ailerons, elevator and rudder. The research project began applying the simplest and the gradual addition of these technologies in order to achieve multi-functional fuel cell systems used by aircraft [13].

\subsection{Boeing Company}

The company is focused, like Airbus, on the production of sustainable aviation bio fuels produced from renewable sources that do not compete with food crops. When creating a global infrastructure it has taken a leading role and promotes the adoption of standards of sustainable bio fuels for aviation.
Since 2008, they have conducted flight tests conducted by airlines and military operators in the operation of aircraft Boeing fueled by bio fuels [15].

Boeing Company is a founding member of the Group for sustainable aviation fuels, which works to reduce greenhouse gas emissions from the operation of commercial aviation. The US Air Force has approved for the entire fleet of Boeing C-17 Globemaster III unrestricted flight operations using bio fuels. Date April 12, 2012 represents a turning point in the history of the manufacturing Boeing consortium. On this day the Boeing 787 Dreamliner flew up combining convenience with fuel efficiency to the production of greenhouse gas carbon dioxide by $30 \%$ lower, compared to similar currently used by large aircraft. The $30 \%$ reduction in emissions is $10 \%$ decrease due to the use of bio fuels and the remaining $20 \%$ has been achieved by applying technological progress, which Dreamliner hides in itself [15].

The global aircraft Boeing manufacturer draws attention not only on the application and use of alternative fuels and solar cells of their aircraft, but also carries out research into promising applications, the fuel cell system, which is achieved through already several times mentioned and demanded reduction of greenhouse gas carbon dioxide and energy efficiency increase [15].

Boeing currently has performed, based on the results of test flights in 2008, the first ever manned flight of aircraft powered with the participation of hydrogen fuel cells which marked a milestone in the history of flight. Boeing sees promising potential uses of hydrogen fuel cells in the capacity of the emergency power backup of electricity in the aircraft. They investigate, in cooperation with Sandia National Laboratories, their application in military and commercial aircraft currently provide backup power to critical subsystems during emergency use various other technologies [15].

\section{Conclusion}

The current high price of oil supports the search for alternative fuels that can provide security and stable prices of fuel and supplies. Work on the development of alternative fuels in aviation has been fully launched and air transport becomes a leader in this field. To promote alternative fuels, it must comply with the environmental benefits, taking fully into account the environment and the costs of production. It is also necessary to identify policies and concepts required for the placing on the market of alternative fuels. Alternative fuels can significantly contribute to the growth of aviation perspective. It should be emphasized that account must be taken of the entire chain of events, and not just emissions from aircraft engines, as well as energy markets, as well as investments in the development and production of alternative fuels and their potential sources. Each of the above mentioned alternatives satisfies the requirement to achieve reductions in greenhouse gas carbon dioxide, as well as reduced consumption of conventional fuels today, resulting in a decrease dependence on oil. 
At the same time a prospective source of electricity seems to be the use of fuel cells in aviation. Most are inflected in conjunction with unmanned aerial vehicles, as well as funds with small crews, which are sufficient for the primary source. These sources of electrical energy presents a promising technology for the production of energy required ancillary systems, especially large commercial aircraft, such as navigation and hydraulic systems.

\section{Acknowledgments}

This research was funded by Ministry of Education, Science, Research and Sport of the Slovak Republic within execution of the project No. ITMS 26220220161 co-financed by EU funds.

\section{References}

[1] J. Pruša et al. World of Air Transport. Galileo CEE, 2008. ISBN 9788080739386.

[2] E. Endrizalová and M. Gandi. Evaluating enviromental impacts of airport operations. Acta Scientifica Academiae Ostroviensis. Sectio A, 7(1):536-544, 2016.

[3] OECD. Green growth and the future of aviation, 2012. URL http://www.oecd.org/ sd-roundtable/papersandpublications / 49482790 .pdf. [Online].

[4] The International Civil Aviation Organization. Why introduce alternative fuels in aviation?, 2014. URL http://www.icao.int/ environmental-protection/Documents / AltFuels/Alternative\%20fuels\% 20 webpage_Questions_Answers_May\% 202014 .docx. [Online].

[5] Engineering National Academies of Sciences and Medicine. Commercial Aircraft Propulsion and Energy Systems Research. The National Academies Press, 2016.

[6] R. Rozenberg and S. Szabo. Základná letecká terminológia. Faculty of Aeronautics, Technical University of Kosice, 2009. ISBN 978-80-553-0304-8.

[7] B. Miller et al. Assessing Opportunities for Alternative Fuel Distribution Programs. Airport Cooperative Research Program, 2013.

[8] A. J. Juanós. Future propulsion systems alternative fuels, 2008. URL http: / / upcommons . upc. edu/ bitstream/handle/2099.1/5326/memoria. pdf? sequence $=1$. [Online].

[9] Lin Lin, Zhou Cunshan, Saritporn Vittayapadung, Shen Xiangqian, and Dong Mingdong. Opportunities and challenges for biodiesel fuel. Applied Energy, 88(4):10201031, 2011.
[10] I. Pahut. Alternative fuels in aviation, 2011. URL http: / / web.tuke.sk/lf/veda_a_vyskum/ Pahut.pdf. [Online].

[11] A. Noth, R. Siegwart, and W. Engel. Design of solar powered airplanes for continuous flight, 2007. URL http: / / www . prog-paradisaea.com/IMG/pdf/ Conceptual_Design_of_Solar_Powered_ Airplanes_for_continuous_flight2.pdf. [Online].

[12] National Space Society. About space solar power (ssp, also known as space-based solar power, or sbsp):, 2016. URL http://wWw.nss.org/ settlement/ssp/. [Online].

[13] Airbus. Eco-efficiency - airbus, commercial aircraft, 2016. URL http://www.airbus.com/ company/eco-efficiency/. [Online].

[14] European Commissionn the biofuel producers and the aviation sector. 2 million tons per year: A performing biofuels supply chain for EU aviation - August 2013 update, 2013. URL https://ec.europa.eu/ energy/sites/ener/files/20130911_a_ performing_biofuels_supply_chain.pof. [Online].

[15] The Boing Company. Commercial aviation and the enviroment, 2014. URL http: / / www . boeing.com/ resources/boeingdotcom/principles/ environment/pdf/ecoMagazine.pdf. [Online]. 